\title{
Menerapkan Kelompok Sel Virtual di Masa Pandemi Covid-19
}

\author{
Irwanto Berutu ${ }^{1}$, Harls Evan R. Siahaan ${ }^{2}$ \\ ${ }^{1}$ Sekolah Tinggi Teologi Paulus Medan, Sumatera utara, Indonesia \\ ${ }^{2}$ Sekolah Tinggi Teologi Pelita Bangsa, Jakarta, Indonesia \\ 1irwantoberutu73@yahoo.com, ${ }^{2}$ evandavidsiahaan@gmail.com
}

\begin{abstract}
: cell groups are important services in church service, because they can have implications for the spiritual growth of the congregation. During the Covid-19 pandemic, all worship activities were restricted, including all programs and services at the local church. In order to maintain the continuity of the worship process, the worship space was created virtually through the use of video streaming technology. This article aims to show that virtual services can also be applied in groups of cells. By using literature studies, and descriptive methods, it was concluded that the Covid-19 pandemic period had virtually stimulated cell group service.
\end{abstract}

Keywords: Covid-19; cell group; digitizing church services; virtual church

\begin{abstract}
Abstrak: kelompok sel merupakan pelayanan yang penting dalam pelayanan gereja, karena dapat berimplikasi pada pertumbuhan rohani jemaat. Di masa pandemi Covid-19 ini semua kegiatan ibadah telah mengalami pembatasan, termasuk semua program dan pelayanan di gereja lokal. Demi mempertahankan keberlangsungan proses ibadah, maka ruang ibadah pun dibuat secara virtual melalui penggunaan teknologi video streaming. Artikel ini bertujuan untuk menunjukkan pelayanan virtual pun dapat diterapkan dalam kelompok sel. Dengan menggunakan studi literatur, dan metode deskriptif, maka disimpulkan bahwa masa pandemi Covid-19 ini telah menstimulasi pelayanan kelompok sel secara virtual.
\end{abstract}

Kata kunci: Covid-19; gereja virtual; kelompok sel; digitalisasi pelayanan gerejawi

\section{PENDAHULUAN}

Kelompok sel merupakan istilah yang tentunya tidak asing lagi dalam dunia kekristenan dan pelayanan gerejawi. Istilah ini biasa digunakan untuk kelompok kecil atau persekutuan kecil yang ada di gereja lokal. Sekalipun istilahnya tidak seragam menggunakan nama "kelompok sel", namun secara prinsip kelompok ini memiliki fungsi yang sama, yaitu persekutuan yang efektif untuk berkomunitas, berinteraksi dengan sesama anggotanya. Tujuan persekutuan secara rohani membawa setiap orang yang mendengarnya menjadi percaya kepada Tuhan Yesus. Persekutuan kecil yang dibentuk orang-orang percaya telah membawa dampak positif pada masa rasul-rasul hingga pada masa kini. Hal tersebut terlihat dengan menyebarnya berita firman Tuhan keseluruh dunia, yang dimulai dari persekutuan orang percaya di Yerusalem.

Kelompok sel sangat berperan dalam meningkatkan iman orang percaya, karena mencakup pembinaan rohani secara terencana. Dalam kelompok sel, setiap orang dibimbing agar dapat terlibat dalam pelayanan sehingga mengalami pertumbuhan menjadi 
jemaat yang dewasa secara rohani (Band: Ef. 4: 14-15). Salah satu karakteristik dari Gereja mula-mula adalah kesukaan mereka dalam bersekutu. ${ }^{1}$ Pemaknaan persekutuan di sini dapat dikonversi sebagai kegiatan kelompok sel yang diadakan di rumah-rumah jemaat, walaupun ada juga yang mengartikan sebagai bentuk atau konsep gereja rumah. ${ }^{2}$ Namun demikian, konsep kelompok sel mengacu pada sebagian kecil orang dari kelompok yang lebih besar untuk bersekutu bersama, dan hal itu dilakukan oleh orang-orang percaya yang dikisahkan dalam Kisah Para Rasul.

Larry Stockstill memberikan gambaran tentang pentingnya kelompok sel, yang tidak akan terputus tetapi tetap memiliki jaringan satu dengan lainnya untuk menyebar sehingga berpotensi untuk perkembangan pelayanan secara pesat, bermultiplikasi dengan cara menerapkan prinsip hidup untuk saling mengasihi satu dengan lainnya. ${ }^{3}$ Terkait dengan hal tersebut, Ruth F. Selan menyebutkan, bahwa salah satu faktor yang menunjukkan kedewasaan rohani jemaat adalah hubungan antar pribadi. ${ }^{4}$ Kelompok sel merupakan persekutuan kecil yang di dalamnya setiap orang dapat berinteraksi secara langsung, berbeda dengan yang terjadi di gereja secara umum dengan jumlah orang yang besar. Itu sebabnya, gereja yang menerapkan kelompok sel dengan baik akan lebih kuat dibandingkan dengan yang hanya mengandalkan ibadah raya setiap hari Minggu untuk memberikan asupan rohani kepada jemaat Tuhan yang ada di dalamnya.

Dalam tiga bulan terakhir kegiatan gereja dan pelayanan yang terkait harus dinonaktifkan oleh karena alasan mewabahnya pandemi Covid-19. Wabah yang menimbulkan dampak di segala sektor, termasuk sosial memaksa harus dihentikannya segala bentuk pertemuan yang melibatkan banyak orang dalam satu tempat. Ini adalah protokol kesehatan terkait ekses pandemi Covid-19, diberlakukannya social distancing. Akibatnya, gereja pun seolah dihentikan pelaksanaan ibadahnya. Walaupun pada awalnya mendapatkan pertentangan dan dinamika pro-kontra terkait "dilarangnya" ibadah di gereja, lambat laun semua pihak pun menyadari esensi dari protokol tersebut, yakni memindahkan ibadah secara komunal di gereja menjadi di rumah.

Beberapa gereja tidak mengalami masalah dengan pemindahan "lokasi" beribadah, yang tadinya di dalam gedung secara fisik, menjadi ruang virtual, dengan mengadopsi teknologi live streaming. Susanto Dwiraharjo menyebutnya dengan istilah gereja digital. ${ }^{5}$ Namun tidak semua gereja mampu mengadaptasikan diri dalam ben-tuk-bentuk digitalisasi tersebut, seperti gereja-gereja kecil, gereja yang di pelosok atau jauh dari jangkauan media internet. Gereja digital menjadi pilihan yang paling dapat mengurai persoalan di era pandemi yang membatasi ruang pertemuan fisik. Itu sebabnya, penting bagi gereja agar mulai

\footnotetext{
${ }^{1}$ Harls Evan Siahaan, "Karakteristik Pentakostalisme Menurut Kisah Para Rasul," DUNAMIS (Jurnal Teologi dan Pendidikan Kristiani) 2, no. 1 (2017): 12-28.

${ }^{2}$ Fransiskus Irwan Widjaja et al., "Menstimulasi Praktik Gereja Rumah Di Tengah Pandemi Covid19,” Kurios (Jurnal Teologi dan Pendidikan Agama Kristen) 6, no. 1 (2020): 127-139, http://www.sttpb.ac.id/e-journal/index.php/kurios/article/view/166.

${ }^{3}$ Larry Stockstill, Gereja Sel, (Jakarta: Metanoia, 2000), 3.

${ }^{4}$ Ruth F.Seland, Pedoman Pembinaan Waga Jemaat, (Bandung, Yayasan Kalam Hidup, 1994), 12

${ }^{5}$ Susanto Dwiraharjo, "Konstruksi Teologis Gereja Digital: Sebuah Refleksi Biblis Ibadah Online Di Masa Pandemi Covid-19," EPIGRAPHE: Jurnal Teologi dan Pelayanan Kristiani 4, no. 1 (2020): 1-17.
} 
"melek" teknologi, bukan sekadar menggunakan media presentasi dalam ibadah, namun ruang digital yang lebih luas bagi dunia pelayanan. Pelayanan yang efektif terkait dengan karunia; dan karunia pelayanan harus diaktualisasikan sesuai kebutuhan dari masa-masa yang berbeda. ${ }^{6}$ Karunia yang diberikan Allah Roh Kudus dalam melayani akan selalu menyesuaikan masanya, tidak harus dipukul rata dari masa para rasul. Artinya, sejumlah karunia yang disebut dalam Alkitab masih akan terus berkembang, karena daftar itu muncul dari sebuah masa yang memiliki gap berbeda dengan era digital masa kini.

Pandemi Covid-19 tidak hanya memberi ruang bagi pelayanan digitalisasi, atau stimulasi gereja digital, namun juga memberi ruang bagi pemaksimalan fungsi gereja rumah. ${ }^{7}$ Beberapa daerah sudah mulai mengadopsi konsep new normal dengan memperhatikan protokol kesehatan. Ruang ibadah pun sudah mulai diperkenan untuk digunakan, termasuk gereja. Beberapa gereja masih menunggu keadaan sampai akhir tahun, dan beberapa sudah mulai melaksanakan pelayanan dengan mengurangi jumlah kehadiran dan merenggangkan tempat duduk para jemaat. Namun, demikian belum semua fungsi pelayanan dalam gereja kembali normal, kecuali ibadah raya di setiap hari Minggu. Namun, pada prinsipnya, pertemuan ibadah sudah diperbolehkan dengan memperhatikan protokol kesehatan.

Pelayanan kelompok sel dapat berimplikasi pada pertumbuhan umat, karena melalui pelayanan dalam kelompok kecil ini semua jemaat dilibatkan untuk melayani Tuhan. Selain itu, pendampingan rohani lebih maksimal dilakukan dalam kelompok kecil, karena tiap pemimpin kelompok sel dapat memonitor perkembangan setiap anggotanya. Daniel Sutoyo mengatakan, kelompok sel merupakan wadah untuk pembelajaran gaya hidup Kristen. ${ }^{8}$ Fungsi kelompok sel bagi pertumbuhan iman jemaat sangat signifikan, sehingga pelayanan ini harus tetap dimaksimalkan dalam keadaan yang bagaimana pun. Di masa pandemi Covid-19 ini pelayanan komsel dapat dimaksimalkan fungsinya, demi meningkatkan kerohanian jemaat Tuhan.

\section{METODE PENELITIAN}

Penelitian ini merupakan penelitian kualitatif yang bertujuan menunjukkan sebuah ruang (kesempatan), baik secara fisik maupun digital, untuk dapat memaksimalkan peran dan fungsi kelompok sel di tengah Pandemi Covid-19. Demi mencapai tujuan tersebut maka penelitian ini menggunakan metode deskriptif fenomenologi yang memanfaatkan berbagai data literatur, atau menerapkan library research. Data mengenai fungsi kelompok sel dalam meningkatkan kerohanian umat, dan situasi yang melingkupi pelayanan gereja di masa pandemi Covid-19 diperoleh dari berbagi literatur seperti jurnal dan buku. Dari data literatur tersebut dideskripsikan, baik keadaan yang melingkupi gereja dan pelayanan kelompok

\footnotetext{
${ }^{6}$ Harls Evan R. Siahaan, “Aktualisasi Pelayanan Karunia Di Era Digital,” EPIGRAPHE: Jurnal Teologi dan Pelayanan Kristiani 1, no. 1 (2017): 23-38, www.stttorsina.ac.id/jurnal/index.php/epigraphe.

${ }^{7}$ Widjaja et al., "Menstimulasi Praktik Gereja Rumah Di Tengah Pandemi Covid-19."

${ }^{8}$ Daniel Sutoyo, "Komunitas Kecil Sebagai Tempat Pembelajaran Gaya Hidup Kristen,” ANTUSIAS: Jurnal Teologi dan Pelayanan 2, no. 2 (2012): 1-26, https://www.sttintheos.ac.id/ejournal/index.php/antusias/article/view/31.
} 
sel sehingga ditemukan beberapa peluang atau kesempatan untuk dapat memaksimalkan pelayanan kelompok sel di masa pandemi Covid-19 ini.

Pandemi Covid-19 dalam konteks ini dipandang sebagai fenomena yang memicu berbagai reaksi. Oleh karena penelitian ini berada dalam lingkup ilmu religiusitas, maka fenomena Covid-19 ini dikaitkan dengan respon keagamaan, yakni sikap gereja dalam melihat sebuah peristiwa terjadi.

\section{PEMBAHASAN}

Steve Barker menuliskan: "Kelompok kecil bukanlah merupakan hasil penemuan Inter Varsity Christian Fellowship (Persekutuan Kristen Antar Universitas)." ${ }^{9}$ Kelompok sel merupakan kelompok kecil di mana orang-orang percaya berkumpul dan setiap anggota kelompok sel mendapat perhatian, baik dari pemimpin kelompok selnya maupun dari sesama anggota kelompok sel lainnya. Tujuannya beragam, bisa untuk mengadakan sharing atau diskusi tentang kebenaran Firman Tuhan, atau saling membagi kesaksian yang dapat membangun iman yang dipandu oleh pemimpin kelompok sel. Dalam kelompok sel ada gerakan yang dilakukan secara simultan untuk mencapai hasil yaitu pertumbuhan iman. Sukamto menambahkan, bahwa pertumbuhan dan perkembangan Gereja Yoido Full Gospel yang berada di Korea Selatan adalah karena kelompok sel. ${ }^{10}$ Hal ini dikonfirmasi oleh Paul Yonggi Cho sebagai pemimpin gereja, "Saya sangat menekankan kepada pentingnya arti mempertahankan kelompok sel Anda sebagai sarana dalam lingkungan gereja Anda untuk melebarkan sayap keluar."11 Pengaruh kelompok sel ini dapat bersifat pertumbuhan rohani dan juga pertambahan jiwa.

Djeffry Hidajat menekankan fungsi persekutuan rumah pada masa Yesus dan rasulrasul sebagai tempat melakukan penginjilan. ${ }^{12}$ Hal ini juga yang terlihat dalam Kisah Para Rasul, bagaimana perkembangan gereja mula-mula terjadi dari persekutuan-persekutuan yang dibangun dari rumah-rumah. Hal senada juga disetujui oleh Cho, bahwa maksud utama diadakannya kelompok sel yaitu untuk menjangkau para tetangga yag berada di sekitar rumah mereka. ${ }^{13}$ Hal ini tentunya harus dipahami dalam konteks masyarakat Korea Selatan, di mana gereja tersebut berada dan berkembang sedemikian rupa. Namun demikian keberadaan persekutuan rumah dalam konteks ini bertujuan untuk dapat mengembangkan kerohanian setiap orang yang ada di dalamnya.

Jika membandingkan dengan masa pelayanan Tuhan Yesus bersama para murid, maka sejatinya Yesus memberi pengajaran yang praktis dan sistematis dengan memberikan teladan hidup-Nya kepada kelompok kecil yang berjumlah 12 itu setiap harinya agar semua murid-murid-Nya dengan cepat mengerti apa yang diajarkan. Setelah Yesus mengajar para murid-murid-Nya, barulah Ia mengutus kedua belas murid tersebut untuk pergi

\footnotetext{
${ }^{9}$ Steve Barker, Pemimpin Kelompok Kecil, (Jakarta: PERKANTAS, 1986), 16.

${ }^{10}$ Sukamto, Rahasia Keberhasilan Gereja di Korea, (Yogyakarta, Penerbit Andi,cet 4 2006), 76.

${ }^{11}$ Paul Yonggi Cho, Bukan Sekedar Jumlah, (Jakarta, Yayasan Pekabaran Injil Immanuel,1985), 69.

${ }^{12}$ Djeffry Hidajat, "Gereja Di Rumah: Kontekstualisasi Fungsi-Fungsi Rumah Dalam Masa Perjanjian Baru Untuk Pekabaran Injil,” Veritas : Jurnal Teologi dan Pelayanan 17, no. 2 (December 2018): 107-117.

${ }^{13}$ Paul Yonggi Cho, Kelompok Sel Yang Berhasil ,(Malang, Penerbit Gandum Mas,1981), 38.
} 
memberitakan Injil. ${ }^{14}$ Pola mengajar di kelompok kecil itu pun berlangsung di masa gereja mula-mula (Kis. 5:42). Tuhan Yesus melakukan pembinaan terhadap murid-murid-Nya dengan cara sederhana, diajar dan dilatih sebagai murid, dengan tetap menjaga kualitas hubungan Guru dengan murid hingga 12 murid dipersiapkan untuk hidup militan dalam pelayanan. Pola kelompok sel terjadi dalam pembinaan kerohanian murid Yesus. Peranan Kelompok sel sangat berdampak bagi pertumbuhan iman murid, ini terlihat ketika Tuhan Yesus sudah terangkat ke surga ke 12 murid mulai melaksanakan misinya sebagai rasul untuk memberitakan Injil kepada semua suku dan bangsa.

\section{Peranan Kelompok Sel}

Pada zaman Kristus hidup di dunia ini, orang-orang percaya berpencar karena penganiayaan, sehingga mereka berkumpul di rumah-rumah untuk beribadah supaya lebih efektif. Pada masa sekarang pun hal itu masih juga terjadi dengan berbagai kesulitan yang dihadapi oleh orang-orang Kristen. Sebagai contoh, gereja-gereja sulit membangun bahkan tidak diberi izin untuk mendirikan gereja, atau izinnya dicabut setelah sekain lama memiliki izin dari pemerintah terkait. Kesulitan-kesulitan beribadah ini sejatinya tidak memengaruhi jalannya ibadah secara hakiki, karena gereja bukan sekadar pertemuan di dalam gedung. Itu sebabnya ada yang mengusulkan untuk memungsikan kembali gereja rumah seperti masa para rasul, di mana mereka berkumpul secara kelompok-kelompok kecil. Jemaat diarahkan untuk menghidupi persekutuan dalam kelompok kecil di rumah-rumah.

Kelompok kecil persekutuan di rumah-rumah, atau gereja rumah dalam konteks pelayanan para rasul merupakan salah satu strategi untuk melaksanakan kegiatan misi amanat agung. Perlu ditandasi bahwa kegiatan misi tidak dapat dilepaskan juga dari konsep perjumpaan budaya ${ }^{15}$, sehingga kegiatan misi para rasul tidak harus mentah-mentah digeneralisir polanya di segala zaman, termasuk di era digital saat ini. Pola gereja rumah bukan berarti usang dalam konteks gereja digital atau virtual, karena belum semua gereja siap dengan implementasi teknologi digitalisasi. Namun, konsep gereja digital dalam konteks ini tidak lepas dari frame persoalan pandemi Covid-19, dalam rangka mengantisipasi "pelarangan" beribadah di gedung gereja.

Jika mengacu pada sistem kelompok sel yang Yesus lakukan, makai Ia memiliki tujuan dengan kelompok sel tersebut, yakni memuridkan kedua belas orang yang telah dipilih untuk meneruskan misi kerajaan Allah. Demikian juga halnya dengan kelompok sel yang dibuat dalam gereja lokal, harus memiliki tujuan bersama untuk memajukan kelompok sel, sehingga anggota-anggotanya dapat bersama-sama bergerak dalam panggilan Tuhan, serta menjadi kelompok sel yang sehat dan bermultiplikasi. Dalam kelompok sel tersedia kesempatan untuk membawa dan membina jiwa-jiwa baru, bahkan melatih semua anggota sel menjadi pemimpin yang melayani.

\footnotetext{
${ }^{14}$ Susanto Dwiraharjo, “Kajian Eksegetikal Amanat Agung Menurut Matius 28 : 18-20,” Jurnal Teologi Gracia Deo 1, no. 2 (2019): 56-73, http://sttbaptisjkt.ac.id/e-journal/index.php/graciadeo. Band: Fransiskus Irwan Widjaja, Daniel Ginting, and Sabar Manahan Hutagalung, "Teologi Misi Sebagai Teologi Amanat Agung," THRONOS: Jurnal Teologi Kristen 1, no. 1 (2019): 17-24.

${ }^{15}$ Abdon A Amtiran, "Memahami Missio Dei Sebagai Suatu Perjumpaan Misioner Dengan Budaya," MAGNUM OPUS: Jurnal Teologi dan Kepemimpinan Kristen 1, no. 1 (2019): 13-21.
} 
Kelompok sel memang berbeda dengan kelas pemuridan, yang secara khusus melatih dan mempersiapkan tenaga-tenaga pelayan Tuhan dalam bidang-bidang tertentu. Contoh saja kelas pemuridan untuk penginjilan, maka hal ini berbeda dengan esensi kelompok sel, meskipun kelompok sel dapat saja memberikan materi tentang memenangkan jiwa atau mengarahkan anggotanya untuk memenangkan jiwa. Eddy Leo menekankan tujuan kelompok sel pada upaya orang Kristen untuk mempraktikkan gaya hidup ilahi dan kasih Allah. ${ }^{16}$ Hal tersebut senada dengan apa yang dikatakan Sutoyo sebelumnya. ${ }^{17}$ Yang penting di sini adalah, memandang kelompok sel sebagai sebuah komunitas, di mana di dalamnya ada interaksi antar anggota sebagai sebuah keluarga Allah.

\section{Tanggung Jawab Pemimpin Kelompok Sel}

Sebuah kelompok sel yang dibentuk harus ada yang bertanggung jawab, biasanya diserahkan kepada ketua kelompok sel. Kepemimpinan seorang ketua kelompok sel sama halnya dengan tanggung jawab seorang gembala, karena pada prinsipnya kepemimpinan seorang ketua kelompok sel merupakan kepempimpinan gembala. Seorang pemimpin harus dapat dipercaya oleh anggota-anggota kelompok sel dan juga orang lain, sehingga memiliki peranan penting untuk kemajuan kelompok selnya. Tanggung jawab pemimpin bukan hanya kepada gembala senior atau penatua gereja yang telah mengangkatnya menjadi ketua, melainkan juga kepada Tuhan Yesus Kristus sebagai kepala dalam gereja serta pemimpin dalam semua bidang pelayanan. Seorang pemimpin kelompok sel mengambil peran gembala yang harus memiliki hubungan yang baik dengan anggota kelompok selnya ${ }^{18}$, bahkan bertanggung jawab atas pertumbuhan kerhohanian anggotanya, dengan cara mendoakan, mengunjungi, memperhatikan, memberi semangat.

Pemimpin kelompok sel, sebagai gembala yang bertanggung jawab atas pertumbuhan rohani anggotanya, harus memiliki pengetahuan yang memadai dalam hal pengajaran firman Tuhan. Dia tidak harus seorang yang pernah mengenyam pendidikan teologi formal dengan gelar sarjana teologi, namun seorang yang suka belajar. ${ }^{19}$ Indikator pertumbuhan rohani memang tidaklah dapat digeneralisir, namun setidaknya ada buah dari kehidupan iman seorang yang percaya kepada Yesus dapat ditunjukkan sebagai indikator pertumbuhan rohani. Itu sebabnya, penting seorang pemimpin kelompok sel memiliki pengetahuan Allkitab yang memadai, yang dapat diperoleh dari banyak cara di era yang memudahkan informasi sekarang ini.

Seorang pemimpin juga harus memiliki kejujuran, keterbukaan kepada anggotaanggota kelompok selnya. Pemimpin harus memberi informasi yang benar, menjadi contoh atau teladan kepada anggotanya. ${ }^{20}$ Pemimpin harus terus bertumbuh. Pemimpin kelompok

\footnotetext{
${ }^{16}$ Eddy Leo, Mengalami Misteri Kristus (Jakarta: Yayasan Media Buana Indonesia, 2002), vi

${ }^{17}$ Sutoyo, "Komunitas Kecil Sebagai Tempat Pembelajaran Gaya Hidup Kristen."

${ }^{18}$ Irwanto Sudibyo, "Pelayanan Kepemimpinan Penggembalaan Menurut Kisah Para Rasul 20:17-38," Jurnal Teologi Gracia DeoGracia Deo 2, no. 1 (2019): 46-61.

${ }^{19}$ Siahaan, "Karakteristik Pentakostalisme Menurut Kisah Para Rasul."

${ }^{20}$ Desti Samarenna and Harls Evan R Siahaan, "Memahami Dan Menerapkan Prinsip Kepemimpinan Orang Muda Menurut 1 Timotius 4:12 Bagi Mahasiswa Teologi," BIA': Jurnal Teologi dan Pendidikan Kristen Kontekstual 2, no. 1 (2019): 1-13, http://www.jurnalbia.com/index.php/bia.
} 
sel berdoa setiap hari bagi semua anggota kelompok selnya. Terutama jiwa baru dan yang sedang dalam pergumulan, merenungkan firman Tuhan setiap hari dalam saat teduh supaya mendapatkan tuntunan Roh Kudus sehingga dapat menggembalakn anggota kelompok sel dengan baik. Kunjungan ke rumah-rumah anggota kelompok sel. Antusias memenangkan jiwa bagi Kristus sebagai petunjuk memberikan teladan kepada anggota kelompok sel.

\section{Memaksimalkan Kekuatan Fungsi Kelompok Sel}

Fungsi kelompok sel setidaknya menjadi wadah persekutuan anggota jemaat dengan jumlah yang lebih kecil. Maksud dari jumlah yang kecil ini adalah kemampuan interaksi dan kontrol yang lebih baik dibandingkan jika anggotanya banyak. Persekutuan ini bukan sekadar melakukan ibadah secara bersama, melainkan juga menjalin sebuah hubungan yang kuat dan erat seperti anggota tubuh. Panggilan dalam mengikut Yesus dan proses menjadi murid itu akan memunculkan sebuah komunitas pengikut Yesus, karena tanpa aspek yang esensial ini maka gereja akan kehilangan hakikatnya sebagai tubuh Kristus, dan tidak berbeda dengan kelompok atau komunitas lainnya. ${ }^{21}$ Orang Kristen hanya akan menjadi anggota semacam klub, datang di hari Minggu, mendengarkan khotbah, bertegur sapa dengan orang di sana, dan segera pergi, tanpa terbina hubungan antara sesama.

Gereja sebagai tubuh Kristus harus memiliki ikatan kebersamaan yang nyata dan terorganisir antar anggota tubuh itu. Kebersamaan yang hanya sekadar datang, menikmati hubungan pribadi dengan Tuhan dalam ibadah, lalu setelah selesai pulang, tidak akan merefleksikan tubuh Kristus yang sebenarnya dan nyata. Itu sebabnya dibutuhkan sebuah bentuk yang nyata untuk tubuh Kristus menyatakan relasi antar anggota, dan itu dapat dilakukan dalam komunitas sel. Pola ini pun yang dilakukan oleh jemaat mula-mula; "Mereka bertekun dalam pengajaran rasul-rasul dan dalam persekutuan. Dan mereka selalu berkumpul untuk memecahkan roti dan berdoa" (Kis 2:42).

\section{Saling Memperhatikan (Peduli)}

Hakikat berkomunitas adalah menjalin hubungan satu dengan yang lain sesuai dengan konsep tubuh Kristus. Artinya, sesama anggota kelompok sel didorong untuk saling memberikan perhatiannya. Hal ini agak sulit diterapkan dalam jemaat di ibadah, karena jumlahnya yang besar. Tetapi, dalam komsel yang baik, Kristus bekerja memberkati setiap anggota, setiap orang menerima dan memiliki hidup Kristus, sehingga mereka saling mengasihi dengan kasih Kristus, saling mendoakan, saling menolong, dan saling membantu (Ef 4:1-6). Hal ini dapat menunjang pertumbuhan rohani setiap anggota, karena dapat berinteraksi langsung untuk saling menguatkan. Inilah yang tercermin dari kelompok jemaat mula-mula, di mana mereka memiliki tingkat kepedulian yang tinggi (Kis. 2:44-45). Mereka hidup saling menolong dan berbagi milik mereka sebagai cermin dari kepedulian Kristus. Kelompok sel memberikan ruang untuk setiap anggota memiliki kepedulian, sikap yang merefleksikan kasih Kristus. Berkomunitas melatih setiap anggotanya memiliki

${ }^{21} \mathrm{https}$ ///cahayapengharapan.org/id/membangun-gereja-pemuridan-di-zaman-ini; diunduh 28 November 2019 
kepedulian dan perhatian tersebut sehingga masing-masing mereka akan dapat mengalami persekutuan yang sejati di dalam kelompok itu.

\section{Mengembangkan Karunia dari Tuhan}

Prinsip komunitas adalah kebersamaan, sekalipun ada keberagaman di dalamnya. Keberagaman yang menunjukkan perbedaan tidak menyurutkan atau bahkan menghentikan keinginan untuk selalu bersekutu bersama. Perbedaan yang ada haruslah dipahami sebagai keberagaman fungsi tubuh yang dikembangkan melalui karunia. Allah memberikan karunia kepada setiap orang berbeda sesuai dengan fungsinya. Berdasarkan kebenaran Firman Tuhan, setiap orang yang sudah bertobat, menerima Kristus dan dilahirkan kembali, memiliki Roh Kudus (Ef. 1:13-14). Roh Kudus itulah yang memberikan karunia-karunia rohani (kharismata) bagi setiap orang percaya (Kis. 2:38; 1Kor 12:4-13, 27-30).

Banyak orang menjadi percaya bertahun-tahun dan kurang memahami tentang karunia-karunia rohani yang Tuhan sediakan untuk gereja-Nya, bahkan mereka tidak mengetahui dengan jelas karunia apa yang dimilikinya. Itulah sebabnya, ia tidak mengalami pertumbuhan secara sehat dan kurang antusias dalam pekerjaan Tuhan. Kelompok sel memiliki fungsi untuk mengembangkan karunia seseorang dalam hal melayani atau yang lainnya. Karunia-karunia rohani yang telah diberikan kepada setiap orang percaya perlu dilatih dan dipraktikkan dalam pelayanan khususnya dalam komsel. Karunia berkaitan dengan pengembangan diri atau jemaat Tuhan. Itu sebabnya masing-masing jemaat harus menyadari dan menemukan karunianya yang unik dalam tubuh Kristus agar dapat mengembangkan dirinya dan komunitas itu pada akhirnya.

\section{Penjangkauan Jiwa}

Pertumbuhan rohani orang percaya tidak dapat dipisahkan dari usaha untuk mengasihi yang terhilang seperti domba yang tersesat. Anggota kelompok sel yang mengalami perjumpaan dengan kasih Kristus memberi dorongan kuat untuk menjangkau jiwa-jiwa baru bagi Tuhan. Tugas ini dapat dikerjakan oleh setiap orang, tetapi akan lebih efektif bila dilaksanakan dalam komsel. Dalam komsel setiap orang dimuridkan, didorong, didoakan, disiapkan, dan dilatih untuk diutus keluar memberitakan Injil, menjangkau orang yang belum percaya bagi Allah sebagai bukti kasih Kristus dalam hidupnya.

Joel Comeskey menyebutkan ada lima unsur yang ada dalam kelompok sel, yakni: kesetiaan, diskusi, penyusunan program, pengerahan, pelipatgandaan. ${ }^{22}$ Pada bagian pelipatgandaan, maka kelompok sel harus melakukan fungsi sebagai pemberita Injil. ${ }^{23}$ Tujuan kelompok sel pada akhirnya adalah menjadi besar dengan cara menambahkan anggotanya. Hal ini tidak mungkin tercapai tanpa adanya kegiatan pemberitaan Injil dari anggotanya. Namun sebelum itu, para anggota harus diajarkan bagaimana cara melakukan itu semua. Di sinilah fungsi kelompok sel sebagai wadah pemuridan terjadi, di mana setiap anggotanya tidak sekadar berkumpul, tapi belajar firman hingga memiliki visi untuk memenangkan

\footnotetext{
${ }^{22}$ Juan Carlos Ortiz, Murid Sejati (Yogyakarta: Yayasan Andi, 1993), 161-168

${ }^{23}$ Wisnu Prabowo, "Menerapkan Prinsip 2 Timotius 1 : 7 Dalam Pelayanan Penginjilan," MAGNUM OPUS: Jurnal Teologi dan Kepemimpinan Kristen 1, no. 1 (2019): 30-45.
} 
jiwa baru. Multiplikasi atau pelipatgandaan hanya terjadi pada gereja yang memberitakan Injil, karena itulah jantung dari gereja yang berbasis sel.

\section{Menjadikan Anggota Setia}

Hal yang tidak kalah penting, bahkan dapat disebut sebagai sentral dalam iman Kristen adalah kesetiaan. Pertemuan ibadah setiap hari Minggu belum dapat memenuhi kebutuhan asupan rohani setiap jemaat untuk bertumbuh. Kelompok sel dapat menjadi tempat untuk setiap jemaat bertumbuh dan tetap setia dalam iman Kristen. Tujuan akhir dari diadakannya kelompok sel adalah membuat anggotanya tetap setia kepada Yesus yang dapat ditunjukkan dengan kesetiaan menjadi anggota gereja lokal. kelompok sel bukan hanya mempersiapkan orang Kristen agar hidup dalam anugerah Allah, tetapi juga menolong orang Kristen agar dapat terus bertahan di masa-masa sulit, seperti menghadapi persoalan pandemi Covid-19 saat ini. Dalam kelompok sel ada nasihat, perhatian, dorongan dan doa dari anggota yang lain, yang dapat dilakukan secara langsung. Kelompok sel merupakan tempat anggota gereja saling memerhatikan, terutama kepada mereka yang menghadapi kesulitan-kesulitan hidup, dengan demikian kelompok sel menjadi hidup dan dinamis.

\section{Strategi Pelaksanaan Kelompok Sel di Masa Pandemi Covid-19}

Ada beberapa strategi yang dapat diterapkan dalam pelayanan penyampaian kabar baik. Umumnya pelayanan secara rutin di hari Minggu dapat disebut dengan Strategi 1-100 (Mat. 5, 6, 7; Kis. 2:14-47). Strategi dengan komunikasi satu arah biasa digunakan dalam khotbah Minggu pagi atau ibadah raya. Strategi ini yang paling umum digunakan oleh gereja-gereja tradisional, dimana dalam semua jenis ibadah, satu orang berbicara dan yang lain hanya mendengarkan. Strategi ini baik digunakan untuk penyembahan bersama, penyampaian informasi secara meluas dan bersifat umum. Kelemahannya ialah tidak mungkin berlangsung komunikasi dua arah yang memungkinkan peran serta aktif semua anggota yang sangat dibutuhkan dalam proses belajar mengajar. Itulah sebabnya, tujuan pendewasaan pribadi setiap anggota sangat sulit dan tidak mungkin tercapai secara efektif.

Kedua, Strategi 1-10, ini adalah kelompok kecil (Mat. 4:18-22). Strategi ini dibutuhkan dan merupakan inti dari konsep kelompok sel yang efektif. Hanya, sayangnya dalam praktiknya belum mengikuti pola yang Yesus pergunakan pada para murid-Nya, dimana Ia mengajar, melatih, mengutus, dan mempersiapkan mereka sebagai pemimpin untuk meneruskan tugas-Nya, setelah Ia kembali ke surga. Strategi ini dilakukan oleh banyak gereja, tetapi hanya sebagai variasi metode di antara semua kegiatan yang diprogramkan. Akibatnya, pola ini tidak menemukan esensinya sebagai sekolah mini, pusat pemuridan, dan dapur pemimpin yang efektif yang memiliki karakter Kristen sesuai dengan citra Kristus. Melalui strategi ini, setiap anggota ditolong mengenal karunianya masing-masing, sehingga dapat melayani secara lebih baik.

Strategi 1-1, pengemban Amanat Agung. Yang dimaksud dengan strategi ini ialah setiap orang yang telah terlatih dengan baik, akan mampu menjadi pengemban Amanat Agung Kristus secara bertanggung jawab. Ini sangat dimungkinkan, sebab ia telah memiliki karakter Kristen yang berdasarkan atas kebenaran dan terus bertumbuh dalam pimpi- 
nan Roh Kudus. Bila setiap orang percaya sudah berada pada tingkatan rohani seperti yang diuraikan dalam Kolose 1:28, maka gereja akan mengalami pemulihan dan penuaian besar menjelang akhir zaman. Perlu ditekankan bahwa strategi 1-1 tidak mungkin tercapai tanpa strategi 1-10 (kelompok sel).

Kelompok sel pada umumnya memiliki format yang tidak jauh berbeda dari ibadah umum, ada doa, pujian dan penyampaian firman Tuhan yang bisa dilakukan dalam bentuk sharing atau refleksi, dan kesaksian. Doa adalah yang paling utama dalam pertumbuhan rohani anggota kelompok sel. Doa adalah nafas hidup orang percaya, yang sederhananya jika tidak berdoa maka tidak ada ke-hidupan, dan tidak mengalami pertumbuhan roh. Perlu diberi waktu yang cukup untuk berdoa, dan bukan sekadar berdoa seperti kebiasaan, namun jemaat dapat mengeks-presikan doanya lebih leluasa. C. Peter Wagner menekankan bahwa doa merupkan senjata utama dari peperangan rohani, bukan sekadar doa yang rutin atau biasa-biasa saja, melainkan doa yang cukup berkuasa untuk menggerakkan tangan Allah demi." ${ }^{24}$ Artinya, doa dalam kelompok sel memperoleh porsi yang sedikit lebih banyak dari ibadah raya hari Minggu.

Selain doa, dalam ibadah kelompok sel juga terdapat pujian dan penyembahan. Sejatinya, baik pujian dan penyembahan dengan doa tidak dapat dipisahkan, karena kedua hal tersebut dapat dilakukan secara tumpeng tindih. Dalam doa terkadang jemaat menyediakan waktu untuk menyembah Tuhan, atau sebaliknya, pujian dan penyembahan dapat menjadi sebuah doa yang dipanjatkan. Pujian dan penyembahan merupakan unsur yang tidak dapat dipisahkan dari ibadah alkitabiah. ${ }^{25}$ Penyembahan merupakan gaya hidup, sikap hidup yang benar-benar hormat karena keagungan, karena kemuliaan, karena kemahakuasaan, karena keajaiban, karena keperkasaan, karena kekudusan Tuhan. Penyembahan berkaian dengan sikap hati yang penuh rasa hormat, tunduk, rendah hati kepada Tuhan Allah Sang Pencipta.

Seperti ibadah pada umumnya, maka dalam kelompok sel pun tetap ada penyampaian firman Tuhan, dengan format yang beragam. Firman Tuhan yang disampaikan bisa membahas khotbah yang disampaikan di ibadah hari Minggu, agar jemaat semakin mengerti. Dalam khotbah yang disampaikan dalam ibadah hari Minggu, jemaat akan terbatas mendengar tanpa bisa melakukan interupsi, bertanya mengenai hal-hal kurang dipahami dalam khotbah tersebut. Namun di dalam ibadah kelompok sel hal tanya jawab sangat mungkin dilakukan, bahkan disarankan, agar jemaat semakin memahami pesan dari khotbah di hari Minggu. Selain itu, penyampaian firman Tuhan dapat berupa sharing, refleksi dengan kesaksian anggota.

Di masa Pandemi Covid-19 ini, di mana kegiatan ibadah dibatasi dengan diberlakukannya protokol kesehatan, hal tersebut pun berdampak pada kegiatan ibadah lain termasuk kegiatan kelompok sel. Namun demikian, penggunaan teknologi pertemuan di ruang digital sangat bisa digunakan dalam konteks ini. Hari-hari ini marak diadakan seminar berbasis online dengan menggunakan beberapa aplikasi seperti Zoom atau Google Meet, yang

\footnotetext{
${ }^{24}$ C. Peter Wagner, Nasib Sebuah Bangsa (Jakarta: Penerbit Nafiri Gabriel, 2003), 6.

${ }^{25}$ Mike dan Viv Hibert, Pelayan Musik (Yogyakarta: Andi Offset ,2001), 14.
} 
berarti pertemuan virtual kelompok sel pun dapat mengadopsi format ini. Aplikasi WhatsApp sudah mengembangkan pertemuan tatap muka video call dengan jumlah lebih dari dua orang. Artinya, teknologi tersebut dapat digunakan untuk melaksanakan kelompok sel di masa yang menerapkan physical distancing.

Ibadah kelompok sel harus tetap berjalan, pun di masa yang penuh keterbatasan dengan mengadopsi teknologi video conference atau virtual meeting yang disediakan oleh beragam aplikasi online meeting. Ada banyak pilihan yang dapat digunakan oleh kelompok sel untuk tetap menjalankan kelompok sel virtual, dari yang gratis hingga berbayar demi mendapat durasi yang lebih lama. Setiap anggota dapat melakukannya seperti di dunia nyata ketika bertemu di rumah-rumah. Memang di awal ada kecanggungan dan butuh waktu untuk beradaptasi menggunakan media online tersebut. Namun, ketika sudah berjalan dalam beberapa waktu dan semua anggota sudah terbiasa, maka semua pola baru itu akan menjadi kebiasaan yang baru.

Sekalipun ada keterbatasan gambar dan suara dalam melakukan petemuan virtual tersebut, seperti suara yang kurang jelas dan delay, namun anggota tidak perlu merasa terganggu atau risih, karena pertemuan sejati ibadah komsel adalah pada dunia rohani, ketika terjalin persekutuan antar anggotanya melalui bantuan media. Setiap anggota tetap berdoa dan memuji serta menyembah Tuhan tanpa memedulikan gangguan teknis yang terjadi. Tetap ada pujian, penyembahan, dan doa melalui pertemuan virtual, dengan durasi yang lebih singkat. Selanjutnya, penyampaian firman Tuhan dalam berbagai format akan lebih mudah dilakukan. Intinya, ada persekutuan dan penyampaian firman, serta doa yang dilakukan anggota sekalipun dalam dunia virtual.

Masa pandemi Covid-19 ini telah menghasilkan banyak ekses, dan tidak sedikit yang merasakan kerugian dan penderitaan terkait dunia kerja dan usaha. Keterbatasan telah memberikan kesempatan untuk pelayanan digital gereja semakin dikembangkan. Persekutuan jemaat atau orang percaya tetap terjalin, sehingga ada kekuatan dalam nasihat dan persekutuan yang dibangun melalui kelompok sel virtual. Sehingga efek buruk yang besar akibat Covid-19 tidak akan menggoncangkan dan meruntuhkan iman orang percaya, karena persekutuan orang percaya melalui kelompok sel virtual tetap berjalan dan semakin memberikan manfaat yang besar bagi pertumbuhan iman jemaat.

\section{KESIMPULAN}

Peran dan fungsi kelompok sel sangat penting bagi pertumbuhan iman, sebab dalam kelompok sel terjalin persekutuan yang saling menguatkan antar anggotanya. Pandemi Covid-19 yang telah membatasi ruang gerak pelayanan dan kegiatan ibadah gerejawi tidak lantas menyurutkan kegiatan persekutuan kelompok sel. Ibadah kelompok sel dapat terus berjalan dengan mengadopsi teknologi virtual meeting yang tersedia di dunia digital. Penelitian ini masih terbatas pada ruang literatur, sehingga belum dapat menyentuh fakta pelaksanaan persekutual sel virtual. Namun demikian, hal ini dapat menjadi penelitian yang dikembangkan selanjunya, tentang tingkat antusiasme jemaat dalam mengikuti persekutuan kelompok sel virtual serta kendala dalam pelaksanaannya. 


\section{REFERENSI}

Amtiran, Abdon A. "Memahami Missio Dei Sebagai Suatu Perjumpaan Misioner Dengan Budaya." MAGNUM OPUS: Jurnal Teologi dan Kepemimpinan Kristen 1, no. 1 (2019): 13-21.

Barker Steve, Pemimpin Kelompok Kecil, Jakarta: PERKANTAS, 1986

Benson S. Warren, Mark H.Senter III, Pedoman lengkap Untuk Pelayanan Kaum Muda, Bandung, Yayasan Kalam Hidup, Jilid II, 1999

Brandt L. Robert, Memenangkan Jiwa, Malang, Penerbit Gandum Mas, Cet I, 1983

Cho Yonggi Paul, Bukan Sekedar Jumlah, Jakarta, Yayasan Pekabaran Injil Immanuel, 1985

Cho Yonggi Paul, Kelompok Sel Yang Berhasil,Malang, Penerbit Gandum Mas, 1981

Dwiraharjo, Susanto. "Kajian Eksegetikal Amanat Agung Menurut Matius 28 : 18-20." Jurnal Teologi Gracia Deo 1, no. 2 (2019): 56-73. http://sttbaptisjkt.ac.id/ejournal/index.php/graciadeo.

Dwiraharjo, Susanto. "Konstruksi Teologis Gereja Digital: Sebuah Refleksi Biblis Ibadah Online Di Masa Pandemi Covid-19.” EPIGRAPHE: Jurnal Teologi dan Pelayanan Kristiani 4, no. 1 (2020): 1-17.

Heath Stauley. Pertumbuhan Gereja Secara Alkitabiah, Jakarta, BPK Gunung Mulia 1989 Hidajat, Djeffry. "Gereja Di Rumah: Kontekstualisasi Fungsi-Fungsi Rumah Dalam Masa Perjanjian Baru Untuk Pekabaran Injil." Veritas : Jurnal Teologi dan Pelayanan 17, no. 2 (December 2018): 107-117.

https://cahayapengharapan.org/id/membangun-gereja-pemuridan-di-zaman-ini; diunduh 28 November 2019

Ortiz, Juan Carlos. Murid Sejati, Yogyakarta: Yayasan Andi, 1993

Prabowo, Wisnu. "Menerapkan Prinsip 2 Timotius 1: 7 Dalam Pelayanan Penginjilan." MAGNUM OPUS: Jurnal Teologi dan Kepemimpinan Kristen 1, no. 1 (2019): 30-45.

Rowlands Gerald, Gereja Saudara Ditetapkan Untuk Bertumbuh, Medan : Internasional Cristian Mission, 2004

Samarenna, Desti, and Harls Evan R Siahaan. "Memahami Dan Menerapkan Prinsip Kepemimpinan Orang Muda Menurut 1 Timotius 4:12 Bagi Mahasiswa Teologi." BIA': Jurnal Teologi dan Pendidikan Kristen Kontekstual 2, no. 1 (2019): 1-13. http://www.jurnalbia.com/index.php/bia.

Seland F. Seland, Pedoman Pembinaan Warga Jemaat, Bandung, Yayasan Kalam Hidup, Cet I, 1994

Siahaan, Harls Evan R. "Karakteristik Pentakostalisme Menurut Kisah Para Rasul." DUNAMIS (Jurnal Teologi dan Pendidikan Kristiani) 2, no. 1 (2017): 12-28.

Siahaan, Harls Evan R. "Aktualisasi Pelayanan Karunia Di Era Digital.” EPIGRAPHE: Jurnal Teologi dan Pelayanan Kristiani 1, no. 1 (2017): 23-38.

www.stttorsina.ac.id/jurnal/index.php/epigraphe.

Stockstill Larry, Gereja Sel, Jakarta: Metanoia, 2000

Sudibyo, Irwanto. "Pelayanan Kepemimpinan Penggembalaan Menurut Kisah Para Rasul 20:17-38." Jurnal Teologi Gracia DeoGracia Deo 2, no. 1 (2019): 46-61.

Suharsimi Arikunto. Prosedur Penelitian, Jakarta: Rineka Cipta, 2006

Sukamto, Rahasia Keberhasilan Gereja di Korea,Yokyakarta, Penerbit ANDI, Cet 4, 2006

Sutoyo, Daniel. "Komunitas Kecil Sebagai Tempat Pembelajaran Gaya Hidup Kristen." ANTUSIAS: Jurnal Teologi dan Pelayanan 2, no. 2 (2012): 1-26. https://www.sttintheos.ac.id/e-journal/index.php/antusias/article/view/31.

Usman Husaini, Metodologi Penelitian Sosial, Jakarta, Penerbit Bumi Aksara, 1996 
Wagner Peter C., Nasib Sebuah Bangsa, Jakarta Penerbit Nafiri Gabriel, 2003

Wagner Peter. Gereja Saudara Dapat Bertumbuh.Malang : Gandum Mas 1990

Widjaja, Fransiskus Irwan, Daniel Ginting, and Sabar Manahan Hutagalung. "Teologi Misi Sebagai Teologi Amanat Agung." THRONOS: Jurnal Teologi Kristen 1, no. 1 (2019): $17-24$.

Widjaja, Fransiskus Irwan, Candra Gunawan Marisi, T. Mangiring Tua Togatorop, and Handreas Hartono. "Menstimulasi Praktik Gereja Rumah Di Tengah Pandemi Covid19.” Kurios (Jurnal Teologi dan Pendidikan Agama Kristen) 6, no. 1 (2020): 127 139. http://www.sttpb.ac.id/e-journal/index.php/kurios/article/view/166.

Yunita Eva, Pemimpin Muda Pada Akhir Zaman, Yogjakarta, Yayasan Andi, Cet. 4, 2006 